\title{
Modulation of Vitamin D Status and Dietary Calcium Affects Bone Mineral Density and Mineral Metabolism in Göttingen Minipigs
}

\author{
Katharina E. Scholz-Ahrens, ${ }^{1,2}$ Claus-Christian Glüer, ${ }^{3}$ Felix Bronner, ${ }^{4}$ \\ Günter Delling, ${ }^{5}$ Yahya Açil, ${ }^{6}$ Hans-Jürgen Hahne, ${ }^{7}$ Joachim Hassenpflug, ${ }^{7}$ \\ Wolfram Timm, ${ }^{3}$ and Jürgen Schrezenmeir ${ }^{1}$ \\ ${ }^{1}$ Institute of Physiology and Biochemistry of Nutrition, Max Rubner-Institut (MRI), Federal Research Institute of Nutrition and \\ Food-Kiel, 24103 Kiel, Germany \\ ${ }^{2}$ Department of Safety and Quality of Milk and Fish Products, Max Rubner-Institut (MRI), Federal Research Institute of Nutrition \\ and Food-Kiel, 24103 Kiel, Germany \\ ${ }^{3}$ Medical Physics Research Group, Department of Diagnostic Radiology, University Hospital Schleswig-Holstein, Campus Kiel, \\ 24105 Kiel, Germany \\ ${ }^{4}$ The University of Connecticut Health Center, Farmington, CT 06030, USA \\ ${ }^{5}$ Department of Osteopathology, University Medical Center Hamburg-Eppendorf, 20246 Hamburg, Germany \\ ${ }^{6}$ Department of Oral and Maxillofacial Surgery, University Hospital Schleswig-Holstein, Campus Kiel, 24105 Kiel, Germany \\ ${ }^{7}$ Department of Orthopaedics, University Hospital Schleswig-Holstein, Campus Kiel, 24105 Kiel, Germany
}

Correspondence should be addressed to Katharina E. Scholz-Ahrens; katharina.scholz-ahrens@mri.bund.de

Received 22 May 2013; Accepted 1 July 2013

Academic Editors: J. L. Pérez-Castrillon and K. Uusi-Rasi

Copyright (C) 2013 Katharina E. Scholz-Ahrens et al. This is an open access article distributed under the Creative Commons Attribution License, which permits unrestricted use, distribution, and reproduction in any medium, provided the original work is properly cited.

Calcium and vitamin D deficiency impairs bone health and may cause rickets in children and osteomalacia in adults. Large animal models are useful to study experimental osteopathies and associated metabolic changes. We intended to modulate vitamin $\mathrm{D}$ status and induce nutritional osteomalacia in minipigs. The control group $(n=9)$ was fed a semisynthetic reference diet with $6 \mathrm{~g}$ calcium and 6,500 IU vitamin $\mathrm{D}_{3} / \mathrm{kg}$ and the experimental group $(n=10)$ the same diet but with only $2 \mathrm{~g}$ calcium/ $\mathrm{kg}$ and without vitamin D. After 15 months, the deficient animals were in negative calcium balance, having lost bone mineral density significantly (means \pm SEM) with $-51.2 \pm 14.7 \mathrm{mg} / \mathrm{cm}^{3}$ in contrast to controls $\left(-2.3 \pm 11.8 \mathrm{mg} / \mathrm{cm}^{3}\right)$, whose calcium balance remained positive. Their osteoid surface was significantly higher, typical of osteomalacia. Their plasma 25(OH)D dropped significantly from $60.1 \pm 11.4 \mathrm{nmol} / \mathrm{L}$ to $15.3 \pm 3.4 \mathrm{nmol} / \mathrm{L}$ within 10 months, whereas that of the control group on the reference diet rose. Urinary phosphorus excretion and plasma 1,25-dihydroxyvitamin D concentrations were significantly higher and final plasma calcium significantly lower than in controls. We conclude that the minipig is a promising large animal model to induce nutritional osteomalacia and to study the time course of hypovitaminosis D and associated functional effects.

\section{Introduction}

Adequate calcium and vitamin $\mathrm{D}$ intakes are essential for skeletal health and to minimize the incidence of osteoporosis and of rickets in children and nutritional osteomalacia in adults. Calcium and vitamin D supplementation is also key to the treatment of these diseases [1-3]. Rickets and osteomalacia remain endemic problems in developing countries but show increasing prevalence also in North America and Europe [3,4] because of changes in life style with an increase of indoor activities and a decrease in sunlight exposure. Incidence of osteomalacia is also increased by the 
demographic shift, because calcium and vitamin D intakes are often inadequate in the elderly, in whom vitamin D synthesis, calcium absorption, and renal reabsorption tend to diminish [3]. Subjects with darker skin or covering clothing habits are at higher risk because both factors contribute to insufficient dermal vitamin $\mathrm{D}$ synthesis, responsible in turn for diminished bone density. Vitamin D combined with calcium has been shown to enhance lower-extremity function when vitamin $\mathrm{D}$ intake was sufficient to assure a serum concentration of 25-hydroxyvitamin D [25(OH)D] that exceeds $75 \mathrm{nmol} / \mathrm{L}$ [5]. This value is much higher than the current normative value of $25 \mathrm{nmol} / \mathrm{L}$, on the basis of which the incidence of rickets/osteomalacia is minimized [1]. Calcium and vitamin D thus have additional metabolic functions, with vitamin $\mathrm{D}$ insufficiency now recognized to be associated with several chronic diseases $[5,6]$. How much vitamin $\mathrm{D}$ is needed to achieve an adequate value for plasma $25(\mathrm{OH}) \mathrm{D}$ is not well known, because the estimate of optimal vitamin $\mathrm{D}$ intake is complicated by several confounding factors that affect vitamin $\mathrm{D}$ status, beside age, diet, and sunlight exposure. Obviously there is no final consensus on the definition of hypovitaminosis, vitamin $\mathrm{D}$ deficiency or insufficiency and on what an optimal $25(\mathrm{OH}) \mathrm{D}$ level is $[1,5$, 7].

It is still difficult to distinguish osteoporotic changes from those of nutritional osteomalacia solely by noninvasive, radiological techniques (quantitative computed tomography, QCT). The loss of apparent bone mineral density (BMD) following rarefaction of trabecular bone, which often is amplified by a calcium and vitamin D shortage, like in osteoporosis, cannot be differentiated from a loss following impaired mineralization of bone tissue, like in moderate osteomalacia. The characteristic feature of nutritional osteomalacia is low bone matrix mineralization combined with enlarged thickness of osteoid tissue in the presence of chronic and severe vitamin D deficiency $[1,8,9]$.

Enlarged osteoid has to be verified histologically on bone biopsies as surface or volume $[8,9]$. To facilitate differentiation of osteomalacia from other low-BMD diseases, like osteoporosis, changes in functional parameters of bone and mineral metabolism may be assessed by use of laboratory markers. Studying the time course of BMD and serum levels of $25(\mathrm{OH}) \mathrm{D}$ and $1,25(\mathrm{OH})_{2} \mathrm{D}$ in human subjects in response to varying calcium and vitamin $\mathrm{D}$ intakes requires an extensive and expensive experimental set-up and is limited by ethical issues. Investigations in animal models may help in this respect and provide a model for preclinical trials with agents modulating vitamin $\mathrm{D}$ metabolism and vitamin $\mathrm{D}$ actions. Experiments with rodents have yielded useful insights, but guidelines application to human therapy of bone diseases, like for osteoporosis, may require studies with larger animal models [10]. In previous publications [11-13] we reported on the utilization of the minipig as a large animal model in metabolic and bone studies including glucocorticoidinduced osteoporosis (GIO). We now report on the long-term effects of vitamin $\mathrm{D}$ and calcium insufficiency on longitudinal and cross-sectional changes of bone mineral density and content, osteoid surface and parameters of bone metabolism compared to a reference group on sufficient intake of calcium and vitamin $\mathrm{D}$. We aimed at assessing whether the minipig can be used for the study of nutritional osteomalacia and the modeling of vitamin D status.

\section{Experimental Methods}

The experiment was approved by the Ministerium für Umwelt, Natur und Forsten des Landes Schleswig-Holstein that regulates animal experiments. The experiment was part of a larger intervention trial with minipigs, in which we investigated the physiologic responses and the composition and properties of bone in this large animal model to various treatments [11, 13].

2.1. Animals, Experimental Groups, and Time Schedule. The experiment was initiated with two groups of ten female primiparous Göttingen minipigs, 30 months old, from the Institute's own breeding herd. They were matched for age and body weight. Blood, urine, and fecal samples were obtained, and $\mathrm{BMD}$ was determined at the beginning of the experiment and at regular intervals thereafter. Animals were sacrificed after 15 months, when bone specimens were obtained. One animal died during anaesthesia.

2.2. Diets, Housing, and Intervention. Until the start of the study, the sows were on the Institute's regular feeding regimen for minipigs (standard diet, $580 \mathrm{~g} / \mathrm{d}$ ) that provided per kg diet: $5 \mathrm{~g}$ calcium, $4 \mathrm{~g}$ phosphorus, $50 \mu \mathrm{g}$ (2000 IU) cholecalciferol (vitamin $\mathrm{D}_{3}$ ), and $9 \mathrm{MJ}$ metabolizable energy. Accordingly, the vitamin D intake was $29 \mu \mathrm{g} / \mathrm{d}(1,160 \mathrm{IU} / \mathrm{d})$ before intervention. The sows were then assigned either to the control group [C] or to the deficient group $[\mathrm{CaD}(-)]$, getting $370 \mathrm{~g} / \mathrm{d}$ of a semipurified diet. The control group was fed a reference diet that contained ( $\mathrm{g} / \mathrm{kg}$ diet) corn starch, 290; sucrose, 240; casein, 150; cellulose, 80; lard, 75; margarine, 75; mineral and vitamin premix, 60; lactulose, 30; and $14 \mathrm{MJ}$ metabolizable energy. The diet contained $6 \mathrm{~g} / \mathrm{kg}$ calcium, $7 \mathrm{~g} / \mathrm{kg}$ phosphorus, and $160 \mu \mathrm{g} / \mathrm{kg}(6,500 \mathrm{IU} / \mathrm{kg})$ of vitamin $\mathrm{D}_{3}$ (Deutsche Vilomix Tierernährung $\mathrm{GmbH}$, Neuenkirchen-Vörden, Germany). Their vitamin D intake was $60 \mu \mathrm{g} / \mathrm{d}(2,400 \mathrm{IU} / \mathrm{d})$. The reference diet was different from a standard diet for pigs because we aimed to mimic a typical western diet (i.e., energy dense, rich in fat and protein, poor in fiber, $\mathrm{Ca}: \mathrm{P}<1$ ), but with mineral and vitamin content sufficient for adult minipigs. This reference diet has been long used in our laboratory for experimental studies without any signs of side effects and was described before [14]. Its vitamin $\mathrm{D}$ content is higher than the standard diet for pigs or values recommended for humans, owing to the matter that less feed was supplied because of the higher energy density of the semisynthetic diet. Furthermore, the experiment was longtermed and without other oral or dermal vitamin D sources. The vitamin $\mathrm{D}$ dose remained below the upper tolerable level for humans of $4000 \mathrm{IU}$ per day and assumed toxicity levels of 10,000 IU/day [1]. The diet was analyzed for protein, calcium, and phosphorus. Animals on the deficient diet were fed the same semisynthetic diet except that it contained only $2 \mathrm{~g} / \mathrm{kg}$ calcium and no vitamin $\mathrm{D}_{3}$. For maintenance of body weights individual feed intake was restricted to $370 \mathrm{~g} / \mathrm{d}$, all 
of which was consumed by all animals. Deionized water was available ad libitum. Animals were housed under controlled conditions on strawless floor cages in individual pens without daylight but artificial light between $06: 00 \mathrm{~h}$ and 18:00 h, temperature between 20 and $22^{\circ} \mathrm{C}$, and $60-70 \%$ humidity. At the end of the experiment, animals were anaesthetized with a combination of Midazolam, ( $1 \mathrm{mg} / \mathrm{kg}$ body weight) and ketamine hydrochloride $(5 \mathrm{mg} / \mathrm{kg}$ body weight; CuraMed Pharma, Karlsruhe, Germany) and sacrificed by exsanguination. Representative bone specimens were stored at $-18^{\circ} \mathrm{C}$.

2.3. Biochemical Parameters. Blood samples were collected between 08:00 and 10:00 after an overnight fast at $t 0$ and after $2,5,7,10,13$, and 15 months ( $t 2$ to $t 15)$. Calcium content was analyzed in EDTA plasma by atomic absorption spectroscopy (Perkin Elmer 1100) with air/acetylene at $2300^{\circ} \mathrm{C}$. Phosphorus was determined in EDTA plasma as inorganic phosphorus with an automatic analyzer (Cobas Bio, Hoffmann La Roche, Basel, Switzerland) and a test kit (Roche Diagnostics GmbH, Mannheim, Germany). PTH was determined in EDTA plasma using a human radioimmunoassay (RIA) (Immundiagnostik, Bensheim, Germany) according to [15]. The kit contained a goat antiserum directed against the C-terminal end of PTH (53-84), with a donkeyanti-goat immunoglobulin as precipitation reagent and a synthetic human PTH fragment as a standard. Values for sensitivity, intra- and interassay variability were $3.4 \mathrm{pg} / \mathrm{L}$, $9.2 \%$ coefficient of variation $(\mathrm{CV})$ and $12.5 \% \mathrm{CV}$, respectively. 25-Hydroxyvitamin D [25(OH)D] was measured in EDTA plasma by RIA (Immundiagnostik, Bensheim, Germany) after acetonitrile precipitation. Values for sensitivity, intraand interassay variability were $2.5 \mathrm{nmol} / \mathrm{L}, 9.8 \% \mathrm{CV}$ and $14 \%$ $\mathrm{CV}$, respectively. 1,25-Dihydroxyvitamin $\mathrm{D}_{3}\left[1,25(\mathrm{OH})_{2} \mathrm{D}\right]$ was measured in EDTA plasma by radio-receptor assay (RRA) (Immundiagnostik, Bensheim, Germany). Values for intra- and interassay variability were $12 \% \mathrm{CV}$ and $17 \% \mathrm{CV}$, respectively. Osteoprotegerin (OPG) was analyzed in serum by sandwich enzyme immunoassay (Immundiagnostik, Bensheim, Germany) in the samples at baseline and after eight months. Values for intra- and interassay variability were $9 \% \mathrm{CV}$ and $<10 \% \mathrm{CV}$, respectively, at a detection limit of $0.14 \mathrm{pmol} / \mathrm{L}$. Bone alkaline phosphatase (BAP) was analyzed in heparin plasma as the difference between total alkaline phosphatase (AP) before and after lectin precipitation, with a kit (Roche Diagnostics GmbH, Mannheim, Germany) based on a kinetic color reaction. Values for intra- and interassay variability were $1.6 \% \mathrm{CV}$ and $2.5 \% \mathrm{CV}$, respectively. Urine was collected for $24 \mathrm{~h}$ at $t 0$ and $t 2$ to $t 15$ and stored frozen at $-18^{\circ} \mathrm{C}$ until analysis. For this, minipigs were individually transferred to metabolic cages for $24 \mathrm{~h}$ that allowed the separate sampling of urine and feces. For technical reasons, urine samples of only 6 animals per group were collected at $t 2$. Calcium and phosphorus were analyzed as described previously. Deoxypyridinoline (DPD) was determined by a preparative reverse-phase-column HPLC as described before [16], using a commercially available bovine bone gelatin (Deutsche Gelatine-Fabriken Baden, Germany) as external standards. All plasma and urine parameters analyses were done in duplicate and blindly.

2.4. Mineral Balance. Metabolic balances were performed at $t 0, t 5, t 10$, and $t 15$. Minipigs were transferred to metabolic cages for 7 days to allow separation of feces and urine. Samples were collected daily and stored at $-18^{\circ} \mathrm{C}$ until analysis. Calcium and phosphorus absorption and retention were calculated on a $\mathrm{mg} / 7$-day basis as follows: absorption $=$ intake - fecal excretion; retention $=$ intake $-($ fecal excretion + urinary excretion). All analyses were done in duplicate and blindly.

2.5. Bone Mineral Density. (BMD) was assessed in vivo in aneasthetized animals by quantitative computed tomography (QCT) with a Siemens Sensation 16 Scanner at $t 0, t 8$, and $t 15$. Trabecular BMD values were evaluated in a central bone slice, $10 \mathrm{~mm}$ thick, and an elliptical region in the anterior part of lumbar vertebrae L1-L3. The Siemens OsteoPackage was used to calculate results. Reproducibility was assessed by duplicate measurements in 4 minipigs with interim repositioning. The root-mean-square (RMS) average of precision [17] was $0.83 \%$ $\left(3.4 \mathrm{mg} / \mathrm{cm}^{3}\right)$.

Bone strength was measured on the 4th lumbar vertebra (L4) as ultimate mechanical stress and calculated as failure load, divided by the cross-sectional area of the cylinders at the point of failure. Compression was tested on thawed cylindrical cancellous bone specimens with a diameter of $7.5 \mathrm{~mm}$ and $10 \mathrm{~mm}$ in length. This had been harvested from the centre of the vertebral bodies according to [18] with the aid of a core drill and a parallel saw. Lumbar vertebrae were fixed and centralized in a bench vise when the drilling was performed from the cover plate to the ground plate under visual inspection to ensure that these specimens consisted solely of trabecular bone. Compression was tested in the Sensotec (Columbus, Ohio) device and deformation in the MTS System (Berlin, Germany). Ultimate strain was measured at the point of failure. Young's modulus was calculated from the slope of the linear portion of the regression of the stress-strain relationship.

2.6. Bone Chemical Composition. Ash, calcium, and phosphorus content were determined on the same crushed cylindrical sample of the 4th lumbar vertebra (L4) after mechanical testing for bone strength. Samples were dried for $4 \mathrm{~h}$ at $105^{\circ} \mathrm{C}$ to determine dry matter (\%). The dried bone was ashed overnight in a muffle furnace at $450^{\circ} \mathrm{C}$; the ash was weighed, dissolved in $20 \%(\mathrm{v} / \mathrm{v}) \mathrm{HCl}$. Calcium and inorganic phosphorus were analyzed as described previously. Bone fat content was determined on a cylindrical sample of exclusively trabecular bone of the last breast vertebra. The sample was ground, hydrolyzed with $4 \mathrm{M} \mathrm{HCl}$, and extracted with petrol ether [19]. Analyses were done in duplicate and blindly.

2.7. Histomorphometry. The 2 nd lumbar vertebrae were used for histomorphometry [20] and evaluated for bone volume/tissue volume (BV/TV), trabecular width (Tb.Wi), trabecular separation (Tb.Sp), osteoid volume/tissue volume 
TABLE 1: Baseline values of age, bone mineral density (BMD), and calciotropic hormones in calcium and vitamin D deficiency osteomalacia.

\begin{tabular}{lcccc}
\hline & \multicolumn{2}{c}{ Control $(n=9)$} & \multicolumn{2}{c}{$\mathrm{CaD}(-)(n=10)$} \\
& Mean & SEM & Mean & SEM \\
\hline Age $(\mathrm{mo})$ & 30 & 0.4 & 29 & 0.6 \\
$\mathrm{BMD}\left(\mathrm{mg} / \mathrm{cm}^{3}\right)$ & 450.2 & 15.9 & 452.5 & 10.9 \\
$25(\mathrm{OH}) \mathrm{D}(\mathrm{nmol} / \mathrm{L})$ & 74.8 & 10.8 & 60.2 & 11.4 \\
$1,25(\mathrm{OH})_{2} \mathrm{D}(\mathrm{pg} / \mathrm{mL})$ & 42.2 & 5.8 & 38.4 & 5.0 \\
PTH $(\mathrm{pmol} / \mathrm{L})$ & 18.5 & 2.2 & 19.9 & 3.6 \\
\hline
\end{tabular}

Mean values and standard error of the mean. There were no significant differences between groups.

(OV/TV), osteoid surface/bone surface (OS/BS), osteoblast surface/bone surface (Ob.S/BS), eroded surface/bone surface (ES/BS), osteoclast surface/bone surface (Oc.S/BS), number of osteoclasts/bone surface (N.Oc/BS), and number of osteoclasts/tissue area (N.Oc/T.Ar).

2.8. Statistical Analysis. Due to the limited number of animals we performed an explorative statistical approach. The statistical package Statgraphics 4.1 (Manugistics, Inc., Rockville, MD, USA) was used to perform the analysis of variance (ANOVA) and to calculate the mean and standard error of the means (SEM). The parameters were distributed normally or in a nearly normal fashion, and differences between the two experimental groups were evaluated by Student's $t$-test (two-sided) for cross-sectional comparison, except for osteoid surface. For this, a one-sided test was applied according to the hypothesis that vitamin D deficiency induces enlarged osteoid. The longitudinal data within groups either as changes from baseline or absolute values were tested by the paired $t$-test at each time point. $P \leq 0.1$ is characterized as a trend, and $P \leq 0.05$ was taken as statistically significant.

\section{Results}

Age, body weight, and characteristics of calcium and bone metabolism at baseline did not differ significantly between the groups (Tables 1-3). Animals on the deficient diet tended to lose weight by $-1.4 \%$ after 5 months and by $-3.7 \%$ after 15 months. Body weights in the control group remained stable (Table 2).

3.1. Osteomalacia. Longitudinally $\mathrm{BMD}$ in vivo $\left(\mathrm{mg} / \mathrm{cm}^{3}\right)$ decreased significantly in animals on the deficient diet (Figure 1(a)). After 15 months, BMD had declined from baseline, equivalent to $-10.6 \%$. BMD of the control animals had declined, equivalent to $-0.6 \%$, and thus had remained stable. For calcium retention we observed a similar picture (Figure 1(b)). The decline from baseline was significant after 5 months until the end. Compared to the controls, there was a trend for lower values at $t 5$ and $t 10$ which became significant at $t 15$, when values of the control group had returned to initial values. The urinary phosphorus excretion increased significantly over time compared to stable values in the control group (Figure 1(c)). In the deficient animals, osteoid surface was 55\% higher than in controls at $t 15(P<$ 0.05 ; Figure 2(a)). At the same time most other bone values were slightly lower in deficient animals compared to controls (Table 4). There was a trend for lower bone wet and dry weights and slightly higher fat content and slightly lower ash weight and ultimate strain (Figures 2(b) and 2(c)). OV/TV, ES/BS, Oc.S/BS, and N.Oc/T.Ar did not differ between groups (not shown).

3.2. Vitamin D Status and Plasma and Urinary Parameters of Bone Metabolism. When animals on our standard diet for minipigs with $2000 \mathrm{IU}$ vitamin D/kg (supplying $29 \mu \mathrm{g} / \mathrm{d}$ ) were assigned to the control group [C] getting the reference diet with $6,500 \mathrm{IU}$ vitamin $\mathrm{D} / \mathrm{kg}$ (supplying $60 \mu \mathrm{g} / \mathrm{d}$ ) at $t 0$, their plasma $25(\mathrm{OH}) \mathrm{D}$ concentrations increased significantly to reach a plateau at $t 10$ (Figure $3(\mathrm{a})$ ), but without augmenting BMD. In the animals on the deficient diet $[\mathrm{CaD}(-)]$, the plasma $25(\mathrm{OH}) \mathrm{D}$ concentration declined significantly and went along with a decrease in BMD. At $t 1525(\mathrm{OH}) \mathrm{D}$ concentrations were $13.9 \pm 2.8 \mathrm{nmol} / \mathrm{L}$ compared to 206 $\pm 33.8 \mathrm{nmol} / \mathrm{L}$ in the control group. In contrast to this $1,25(\mathrm{OH})_{2} \mathrm{D}$ levels increased in the deficient group from the beginning and were significantly higher than in the controls most of the time (Figure 3(b)), whose values had slightly increased over the second time period. In the deficient group plasma PTH concentrations tended to be higher than in the control group between $t 8$ and $t 13$ (Figure $3(\mathrm{c})$ ). In that time period their values slightly increased while those of the control group slightly decreased. Plasma calcium declined and was significantly lower than in the controls after 15 months (Table 2). Urinary DPD slightly declined with time in the control group, but without being significantly different from the deficient group.

3.3. Mineral Absorption. After 5 months and until the end of the experiment, the fecal calcium excretion was significantly lower in the deficient group compared to the controls (Table 3) because of the low calcium content of that diet, amplified by the lack of vitamin $\mathrm{D}$. These animals were in a negative calcium balance and had significantly lower values for calcium retention (Figure 1). Phosphorus intake (17.1 g/7d) was the same in both groups. Fecal phosphorus was highly variable in each group but did not differ between groups (Table 3).

\section{Discussion}

Of the many disorders that lead to rickets/osteomalacia, vitamin $\mathrm{D}$ deficiency and/or calcium insufficiency or its malabsorption are the most common $[1,21]$. The dose effect of vitamin D from food on plasma concentrations of $25(\mathrm{OH}) \mathrm{D}$ and the dose effect of plasma $25(\mathrm{OH}) \mathrm{D}$ on bone health is still a matter of debate. Until recently the recommended daily intake (RDI) of vitamin D varied from 5 to $15 \mu \mathrm{g} / \mathrm{d}(20 \mu \mathrm{g} / \mathrm{d}$ for older adults) in the United States and parts of Europe but was recently increased for adults to $15 \mu \mathrm{g} / \mathrm{d}$ [1] or $20 \mu \mathrm{g} / \mathrm{d}$ 
TABLE 2: Baseline values and time course of body weights and markers of calcium metabolism and bone turnover in calcium and vitamin $\mathrm{D}$ deficiency osteomalacia.

\begin{tabular}{|c|c|c|c|c|c|c|c|c|c|c|c|c|}
\hline & \multicolumn{6}{|c|}{ Control $(n=9)$} & \multicolumn{6}{|c|}{$\mathrm{CaD}(-)(n=10)$} \\
\hline & \multicolumn{2}{|c|}{ to } & \multicolumn{2}{|c|}{$t 8$} & \multicolumn{2}{|c|}{$t 15$} & \multicolumn{2}{|c|}{ to } & \multicolumn{2}{|c|}{$t 8$} & \multicolumn{2}{|c|}{$t 15$} \\
\hline & Mean & SEM & Mean & SEM & Mean & SEM & Mean & SEM & Mean & SEM & Mean & SEM \\
\hline Body weight (kg) & 33.1 & 1.6 & 33.5 & 1.3 & 33.1 & 1.3 & 32.4 & 1.8 & 32.0 & 1.2 & 31.2 & 1.5 \\
\hline \multicolumn{13}{|l|}{ Plasma } \\
\hline $\mathrm{Ca}(\mathrm{mg} / \mathrm{L})$ & 110.1 & 3.3 & 107.6 & 2.4 & 107.6 & 2.2 & 111.0 & 1.9 & 108.5 & 1.6 & 101.5 & $1.5^{\mathrm{a}, \mathrm{x}}$ \\
\hline $\mathrm{P}(\mathrm{mg} / \mathrm{L})$ & 49.7 & 1.9 & 46.7 & 2.7 & 52.7 & 2.1 & 49.5 & 2.4 & 47.7 & 0.8 & 50.1 & 1.3 \\
\hline $\mathrm{AP}(\mathrm{U} / \mathrm{L})$ & 116.9 & 28.9 & 153.5 & 59.6 & 185.0 & 75.2 & 139.1 & 23.4 & 200.7 & $44.1^{\mathrm{x}}$ & 169.2 & 22.3 \\
\hline $\mathrm{BAP}(\mathrm{U} / \mathrm{L})$ & 29.6 & 4.6 & 29.6 & 4.2 & 23.3 & 3.2 & 38.0 & 4.9 & 36.1 & 4.6 & 36.0 & $5.8^{[\mathrm{a}]}$ \\
\hline OPG (pmol/L) & 0.9 & 0.1 & 0.6 & 0.1 & nd & & 0.8 & 0.1 & 0.73 & $0.04^{[\mathrm{x}]}$ & nd & \\
\hline \multicolumn{13}{|l|}{ Urine } \\
\hline DPD (nmol/24 h) & 139.9 & 25.5 & 116.0 & 12.2 & 84.3 & 12.2 & 120.3 & 2.3 & 128.3 & 16.9 & 81.8 & 7.6 \\
\hline DPD/Crea $(\mathrm{nmol} / \mathrm{mmol})$ & 10.1 & 3.2 & 6.2 & 0.7 & 6.7 & 1.6 & 11.8 & 2.9 & 5.5 & $0.9^{[\mathrm{x}]}$ & 5.5 & 0.9 \\
\hline
\end{tabular}

Mean values and standard error of the mean. AP: total alkaline phosphatase; BAP: bone alkaline phosphatase, OPG: osteoprotegerin; nd: not determined; DPD: deoxypyridinoline; Crea: creatinine. Samples are 8-10. Significantly different from the value of the control group at the same time point with ${ }^{[\mathrm{a}]} P \leq 0.1$; ${ }^{\mathrm{a}} P \leq 0.05$. Significantly different from the baseline value with ${ }^{[\mathrm{x}]} P \leq 0.1 ;{ }^{\mathrm{x}} P \leq 0.05$.

TABLE 3: Baseline and final values of calcium and phosphorus balances in calcium and vitamin D deficiency osteomalacia.

\begin{tabular}{|c|c|c|c|c|c|c|c|c|}
\hline & \multicolumn{4}{|c|}{ Control $(n=9)$} & \multicolumn{4}{|c|}{$\mathrm{CaD}(-)(n=10)$} \\
\hline & \multicolumn{2}{|c|}{ Baseline $(t 0)$} & \multicolumn{2}{|c|}{ Final $(t 15)$} & \multicolumn{2}{|c|}{ Baseline $(t 0)$} & \multicolumn{2}{|c|}{ Final $(t 15)$} \\
\hline & Mean & SEM & Mean & SEM & Mean & SEM & Mean & SEM \\
\hline Ca intake (mg/7d) & 15540 & & 15540 & & 15540 & & 5180 & \\
\hline Faecal Ca (mg/7d) & 13699 & 850 & 13833 & 1232 & 12558 & 1079 & 8373 & $2258^{\mathrm{a},[\mathrm{x}]}$ \\
\hline Urinary Ca (mg/7d) & 431 & 79 & 391 & 68 & 383 & 33 & 460 & 85 \\
\hline Ca absorption (mg/7d) & 1841 & 850 & 1707 & 1232 & 2982 & 1079 & -3193 & $2258^{[\mathrm{a}], \mathrm{x}}$ \\
\hline Ca retention $(\mathrm{mg} / 7 \mathrm{~d})$ & 1410 & 893 & 1316 & 1261 & 2599 & 1094 & -3654 & $2231^{[\mathrm{a}], \mathrm{x}}$ \\
\hline P intake $(\mathrm{mg} / 7 \mathrm{~d})$ & 17094 & & 17094 & & 17094 & & 17094 & \\
\hline Faecal P (mg/7d) & 16433 & 1669 & 14050 & 1116 & 14161 & 1090 & 12336 & 2186 \\
\hline Urinary P (mg/7d) & 1103 & 198 & 1196 & 178 & 1540 & 299 & 3207 & $545^{\mathrm{b}, \mathrm{x}}$ \\
\hline P absorption (mg/7d) & 661 & 1669 & 3044 & 1116 & 2933 & 1090 & 4758 & 2186 \\
\hline $\mathrm{P}$ retention $(\mathrm{mg} / 7 \mathrm{~d})$ & -441 & 1666 & 1848 & 1158 & 1393 & 991 & 1551 & 2235 \\
\hline
\end{tabular}

Mean values and standard error of the mean. Significantly different from the value of the control group at the same time point with ${ }^{[\mathrm{a}]} P \leq 0.1 ;{ }^{\mathrm{a}} P \leq 0.05$; ${ }^{\mathrm{b}} P \leq$ $0.01 ;{ }^{\mathrm{c}} P \leq 0.001$. Significantly different from the baseline value with ${ }^{[\mathrm{x}]} P \leq 0.1 ;{ }^{\mathrm{x}} P \leq 0.05$.

[22] or is still limited to small children and the aged [23]. These doses did not take into account the pleiotropic effects of vitamin D [5,24]. There are still open questions concerning vitamin $\mathrm{D}$ and calcium mediated effects on bone metabolism but also on extraskeletal issues like immunity, cardiovascular system, cancerogenesis, and central nervous system $[1,5]$. Often effects and mechanisms can be more easily studied in animal models than in humans.

4.1. Animal Model. The pig and minipig have long been known as models for biomedical and nutritional research [25-27]. The pig, like the human, is omnivorous and, having evolved like man with significant exposure to sunlight, photochemically converts 7-dehydrocholesterol to cholecalciferol. The rat, in contrast, is nocturnal, with ergocalciferol its main source of vitamin $\mathrm{D}$, and therefore might be less well suited for the study of vitamin D metabolism [28]. Also, because of their size, minipigs can be utilized in routine apparatus for osteodensitometry to study bone health [11, 13]. Minipigs, unlike rats or sheep, develop glucocorticosteroidinduced osteoporosis (GIO) without the need for simultaneous ovariectomy [13]. We have shown earlier that GIO can be monitored by measurement of bone mineral density [11, 13] and is accompanied by changes in cartilage matrix [29] and bone tissue vascularisation [30].

Basal plasma 25(OH)D concentrations in the minipigs were $60 \mathrm{nmol} / \mathrm{L}$ and $75 \mathrm{nmol} / \mathrm{L}$ and thus were higher than concentrations in young men with very low vitamin $D$ intakes of $200 \mathrm{IU} /$ day but were comparable after the men had been supplemented with 1,800 IU/day. This amount refers to a total of $25 \mathrm{IU}$ vitamin $\mathrm{D} / \mathrm{kg}$ body wt/d compared with the $35 \mathrm{IU}$ vitamin $\mathrm{D} / \mathrm{kg}$ body wt/day in the minipigs. In young growing minipiglets plasma $25(\mathrm{OH}) \mathrm{D}$ concentrations of $340 \mathrm{nmol} / \mathrm{L}$ were observed when animals were on semisynthetic diets containing $8 \mathrm{~g}$ calcium $/ \mathrm{kg}$ diet and 6,500 IU/kg diet vitamin $\mathrm{D}_{3}$, whereas their levels were $40 \mathrm{nmol} / \mathrm{L}$ after they had 


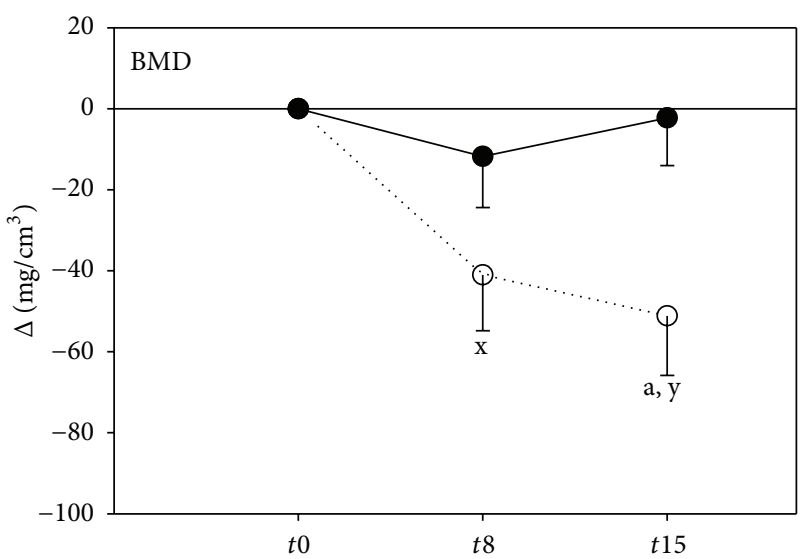

(a)

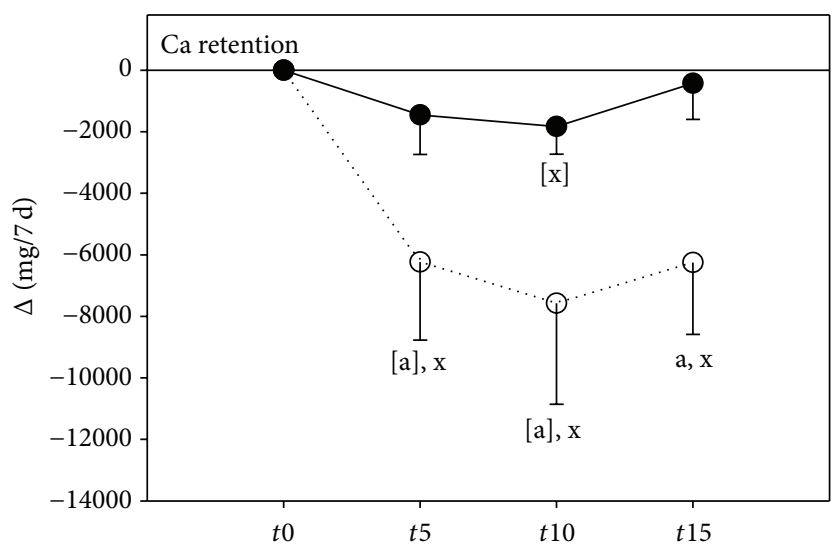

(b)

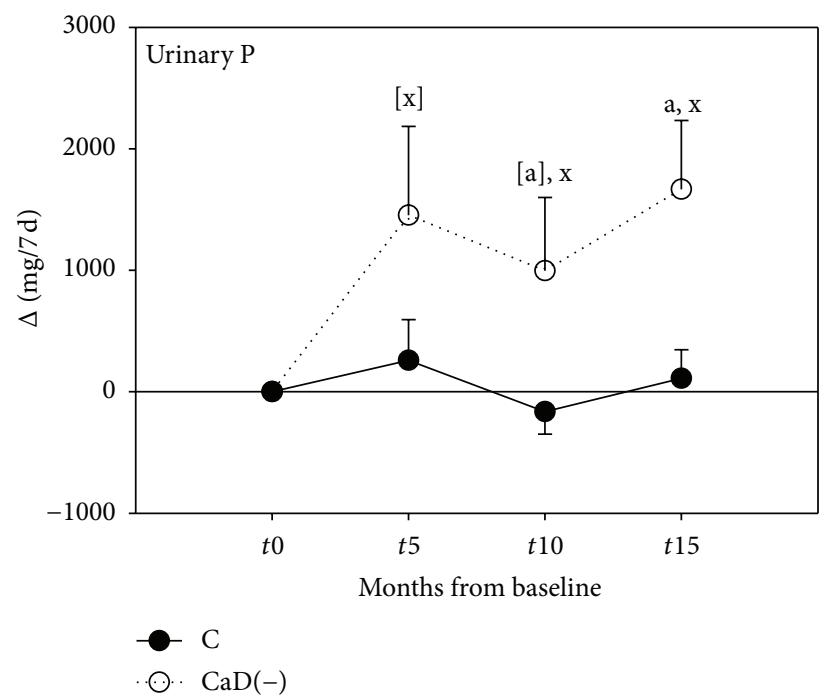

(c)

FIgURE 1: Effects of calcium and vitamin D deficiency [CaD(-); dotted line] on bone mineral density (BMD, (a)), calcium retention (b), and urinary excretion of phosphorus, (c), compared with a control group (C; solid line). Values are changes from baseline $t 0$, with baseline values assigned to zero. Means and SEM, $n=8-10$. Significantly different from the controls at a given time: ${ }^{[\mathrm{a}]} P<0.1$ (trend); ${ }^{\mathrm{a}} P \leq 0.05$. Significantly different from baseline: ${ }^{[\mathrm{x}]} P \leq 0.1 ;{ }^{\mathrm{x}} P \leq 0.05 ;{ }^{\mathrm{y}} P \leq 0.01$.

consumed the same diet but devoid of vitamin D for 8 weeks [26]. In intact and ovariectomized adult domestic pigs on conventional feed, $25(\mathrm{OH}) \mathrm{D}$ concentrations were between 180 and $250 \mathrm{nmol} / \mathrm{L}$ [31]. In a study on the safety of oral $25(\mathrm{OH}) \mathrm{D}$ in growing pigs a wide range of plasma $25(\mathrm{OH}) \mathrm{D}$ was achieved without affecting numerous biological variables adversely [32]. Obviously high vitamin D supplies or comparatively high plasma $25(\mathrm{OH}) \mathrm{D}$ concentrations do not arouse toxicity or induce adverse effects on a large number of variables including those of mineral metabolism. In humans up to $10,000 \mathrm{IU} / \mathrm{d}$ of vitamin $\mathrm{D}_{3}$ were assumed to pose no risk of toxicity [33].

4.2. Modulation of Vitamin D Status-Control. When the control minipigs were switched from their $580 \mathrm{~g} / \mathrm{d}$ standard diet to the $370 \mathrm{~g} / \mathrm{d}$ reference diet (at $t 0$ ), their average daily intake of vitamin $\mathrm{D}_{3}$ increased from $29 \mu \mathrm{g} / \mathrm{d}(1,160 \mathrm{IU} / \mathrm{d}$;
$0.88 \mu \mathrm{g} / \mathrm{kg} \mathrm{BW})$ to $60 \mu \mathrm{g} / \mathrm{d}(2,400 \mathrm{IU} / \mathrm{d} ; 1.83 \mu \mathrm{g} / \mathrm{kg} \mathrm{BW})$ due to the different vitamin $\mathrm{D}_{3}$ contents and amounts of feed supplied. At the same time their mean baseline plasma $25(\mathrm{OH}) \mathrm{D}$ concentration of $75 \mathrm{nmol} / \mathrm{L}$ increased significantly within five months, with final values of $206 \mathrm{nmol} / \mathrm{L}$ at $t 15$.

Accordingly, the relation between increase of plasma $25(\mathrm{OH}) \mathrm{D}(131 \mathrm{nmol} / \mathrm{L})$ and vitamin $\mathrm{D}$ intake or supplement $(31 \mu \mathrm{g} / \mathrm{d})$, also calculated as the efficacy or efficiency of dietary vitamin D on vitamin D status, was approximately $4.2 \mathrm{nmol} / \mathrm{L}$ per $\mu \mathrm{g} / \mathrm{d}$. In human studies, these values ranging between 0.6 and $2.9 \mathrm{nmol} / \mathrm{L}$ per $\mu \mathrm{g} / \mathrm{d}$ were reported [34-38]. For example, when food was fortified over a range of $3-25 \mu \mathrm{g} / \mathrm{d}$ vitamin $\mathrm{D}$, the plasma $25(\mathrm{OH}) \mathrm{D}$ concentration rose over a range of 14 and $35 \mathrm{nmol} / \mathrm{L}$ [37]. In elderly people, a daily intake of bread for 12 months fortified with $320 \mathrm{mg}$ calcium and $125 \mu \mathrm{g}$ vitamin $\mathrm{D}(5000 \mathrm{IU})$ equivalent to $1.7 \mu \mathrm{g} / \mathrm{kg}$ body weight and thus comparable to our supplemented animals increased 


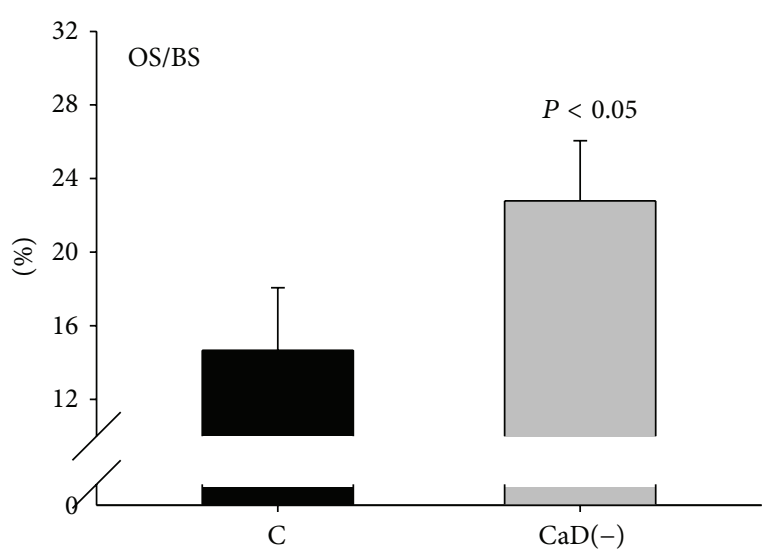

(a)

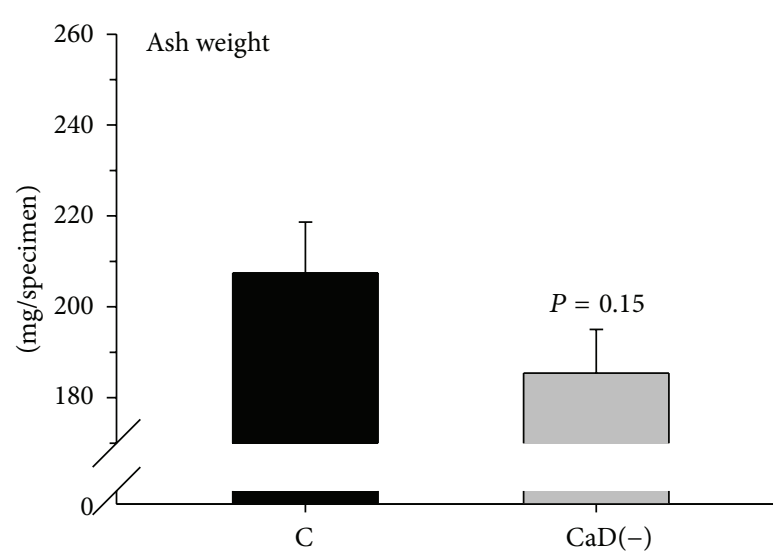

(b)

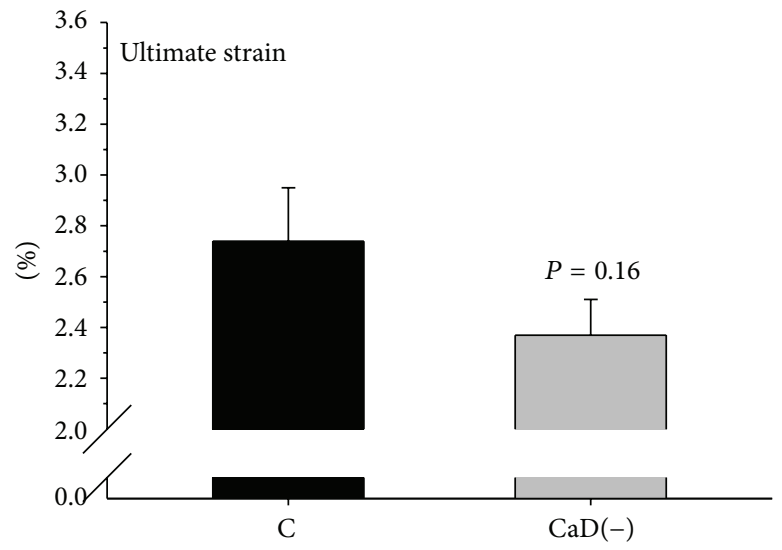

(c)

FIGURE 2: Effects of calcium and vitamin D deficiency [CaD(-)] on osteoid surface [OS/BS], (a), bone ash weight (b), and ultimate mechanical strain (c) compared with a control group [C]. Means and SEM, $n=8-10 . P<0.05=$ significantly different from the control group.

their plasma 25(OH)D from 28 to $125 \mathrm{nmol} / \mathrm{L}$, representing a relation of $0.8 \mathrm{nmol} / \mathrm{L}$ per $\mu \mathrm{g} / \mathrm{d}$ [36]. The efficiency values from several human studies were thus lower than those in minipigs. The reason may be a higher amount of ingested and thus absorbed vitamin D due to $100 \%$ compliance in this trial, unlike in human studies. In addition, a higher hepatic conversion to $25(\mathrm{OH}) \mathrm{D}$ in the minipigs might be assumed because of their younger biological age compared to elderly subjects.

Nearly $40 \mu \mathrm{g}$ of vitamin D/d (1,600 IU/d; $0.51 \mu \mathrm{g} / \mathrm{kg} \mathrm{BW)}$ seems to ensure winter serum $25(\mathrm{OH}) \mathrm{D}$ concentrations higher than $80 \mathrm{nmol} / \mathrm{L}$ in $97.5 \%$ of the study population [34]. Participants in an Antarctic expedition were supplemented with 10,25 , or $50 \mu \mathrm{g} / \mathrm{d}(0.11,0.28$, or $0.55 \mu \mathrm{g} / \mathrm{kg} \mathrm{BW})$. Their plasma $25(\mathrm{OH}) \mathrm{D}$ baseline concentration of $40 \mathrm{nmol} / \mathrm{L}$ increased to 57,63 , and $71 \mathrm{nmol} / \mathrm{L}$, respectively [39], whereas in individuals without supplement plasma $25(\mathrm{OH}) \mathrm{D}$ concentrations remained at baseline. In these studies $[34,39]$ the plasma $25(\mathrm{OH}) \mathrm{D}$ level after supplementation was similar to the baseline level in the minipigs (about $75 \mathrm{nmol} / \mathrm{L}$ ) when getting the standard diet but was achieved with less vitamin $\mathrm{D} / \mathrm{kg}$ BW, possibly because of summertime dermal synthesis and resultant higher body stores. In minipigs concentrations after supplementation stabilized around $200 \mathrm{nmol} / \mathrm{L}$, and such high values have also been reported for subjects at the end of the summer period after having had extended outdoor activities [40]. Since some years ago there is increasing agreement on a higher upper tolerable level of vitamin D intake without reaching toxicity and of higher plasma values of $25(\mathrm{OH}) \mathrm{D}$ without having adverse physiological effects [33, 40-43]. This is also expressed in the elevation of the tolerable upper intake level (UL) of $2000 \mathrm{IU} / \mathrm{d}$ up to $4000 \mathrm{IU} / \mathrm{d}$ by the Institute of Medicine [1]. The supply with vitamin D of $2,400 \mathrm{IU} / \mathrm{d}$ in this trial remained below the upper tolerable level, even though the efficiency between vitamin $\mathrm{D}$ supply and plasma levels of $25(\mathrm{OH}) \mathrm{D}$ may be somewhat higher in young adult minipigs compared to aged adult humans. The plasma levels approximated a steady state after 15 months of supplementation, which is below the assumed level of toxicity of $500 \mathrm{nmol} / \mathrm{L}[42,43]$. This is in accordance with normocalcemia during intervention and lack of any other signs of toxicity in the animals. In order to attain mean $25(\mathrm{OH}) \mathrm{D}$ levels of about $50 \mathrm{nmol} / \mathrm{L}$ in the minipigs, about $23 \mathrm{ng} / \mathrm{d}$ (920 IU/D) might be sufficient, supposed that the 
TABLE 4: Cross-sectional effects of calcium and vitamin D deficiency osteomalacia on chemical composition, material properties, in vivo $\mathrm{BMD}$, and morphology in bone specimen at $t 15$.

\begin{tabular}{|c|c|c|c|c|}
\hline & \multicolumn{2}{|c|}{ Control $(n=9)$} & \multicolumn{2}{|c|}{$\mathrm{CaD}(-)(n=10)$} \\
\hline & Mean & SEM & Mean & SEM \\
\hline \multicolumn{5}{|l|}{ 4th lumbar vertebra } \\
\hline Bone wet weight $(\mathrm{mg})^{\mathrm{b}}$ & 594 & 17 & 550 & $16^{[\mathrm{a}]}$ \\
\hline Bone dry weight $(\mathrm{mg})^{\mathrm{b}}$ & 350 & 12 & 318 & $12^{[\mathrm{a}]}$ \\
\hline Organic matter $(\mathrm{mg})^{\mathrm{b}}$ & 143 & 7 & 133 & 5 \\
\hline Calcium $(\mathrm{mg})^{\mathrm{b}}$ & 128.7 & 4.1 & 125.1 & 2.9 \\
\hline Phosphorus (mg) ${ }^{b}$ & 59.6 & 2.1 & 57.5 & 1.3 \\
\hline Fat $(\mathrm{mg})^{\mathrm{c}, \mathrm{d}}$ & 8.3 & 1.4 & 9.3 & 1.3 \\
\hline Young's modulus (MPa) & 1952 & 145 & 1793 & 150 \\
\hline Breaking load $(\mathrm{N})$ & 1118 & 80 & 973 & 72 \\
\hline Ultimate stress (MPa) & 25.3 & 1.8 & 22.0 & 1.6 \\
\hline \multicolumn{5}{|l|}{ 2nd lumbar vertebra } \\
\hline $\mathrm{BMD}^{\mathrm{e}}\left(\mathrm{mg} / \mathrm{cm}^{3}\right)$ & 447.5 & 20.9 & 404.5 & 17.2 \\
\hline $\mathrm{BV} / \mathrm{TV}(\%)$ & 34.0 & 3.1 & 30.7 & 1.8 \\
\hline $\mathrm{BMD} /(\mathrm{BV} / \mathrm{TV})^{\mathrm{f}}(\mathrm{g} / \mathrm{mL})$ & 1.4 & 0.2 & 1.3 & 0.3 \\
\hline Tb.Wi $(\mu \mathrm{m})$ & 121.6 & 10.7 & 106.4 & 7.1 \\
\hline $\mathrm{Tb} . \mathrm{Sp}(\mu \mathrm{m})$ & 245.4 & 26.0 & 242.5 & 15.0 \\
\hline Ob.S/BS (\%) & 4.0 & 2.1 & 6.4 & 2.8 \\
\hline N.Oc/BS (p.mm) & 0.8 & 0.2 & 1.0 & 0.3 \\
\hline
\end{tabular}

Mean values and standard error of the mean. The chemical composition and material properties were determined on the same cylindrical specimen. The 2nd lumbar vertebrae were analysed morphologically $(n=8-10)$. BV/TV: bone volume/tissue volume; BMD: bone mineral density; Tb.Wi: trabecular width; Tb.Sp: trabecular separation; Ob.S/BS: osteoblast surface/bone surface; N.Oc/BS: number of osteoclasts/bone surface. None of the differences reached statistical significance, ${ }^{[\mathrm{a}]} P \leq 0.1 .{ }^{\mathrm{b}} \mathrm{mg} / \mathrm{cylin}$ drical sample; ${ }^{\mathrm{c}} \mathrm{mg} / 100 \mathrm{mg}$ bone wet weight; ${ }^{\mathrm{d}}$ in the last breast vertebra; ${ }^{\mathrm{e}}$ in vivo in L1-L3; ${ }^{\mathrm{f}}$ indicates mineralisation of bone tissue.

calculated efficacy of $4.2 \mathrm{nmol} / \mathrm{L}$ per $\mu \mathrm{g} / \mathrm{d}$ is applicable at this lower scale of plasma values. The actual vitamin $\mathrm{D}$ demand might even be less, because a higher efficacy can be assumed at lower baseline values for 25(OH)D [41].

4.3. Modulation of Vitamin D Status-Deprivation. Vitamin $\mathrm{D}$ insufficiency or mild deficiency is characterized by $25(\mathrm{OH}) \mathrm{D}$ plasma concentrations less than $50 \mathrm{nmol} / \mathrm{L}$, whereas moderate deficiency is defined by levels less than $25 \mathrm{nmol} / \mathrm{L}$. In severe vitamin $\mathrm{D}$ deficiency, the mean value is lower than $10.6 \mathrm{nmol} / \mathrm{L}$ [44]. Accordingly the animals of the experimental group developed mild deficiency within five months and moderate deficiency within 10 months when mean plasma concentrations were between 15 and $20 \mathrm{nmol} / \mathrm{L}$. Whether $25(\mathrm{OH}) \mathrm{D}$ and $1,25(\mathrm{OH})_{2} \mathrm{D}$ plasma concentrations vary in the same direction or affect each other and how their levels influence calcium absorption and BMC is not yet well established $[45,46]$. In untreated nutritional osteomalacia with low levels of $25(\mathrm{OH}) \mathrm{D}, 1,25(\mathrm{OH})_{2} \mathrm{D}$ concentrations have been found normal [45]. In another study both vitamin $\mathrm{D}$ metabolites varied into the same direction when $25(\mathrm{OH}) \mathrm{D}$ concentrations were above $41 \mathrm{nmol} / \mathrm{L}$ but varied inversely at lower concentrations [46]. Thus, the direction of association may depend on the vitamin D status. It is generally assumed that the major effect of vitamin $\mathrm{D}$ on bone is mediated by $1,25(\mathrm{OH})_{2} \mathrm{D}$, although $25(\mathrm{OH}) \mathrm{D}$ may have a direct effect on bone [46]. We regard the low calcium content of the deficient diet as the primary cause of the rise of plasma $1,25(\mathrm{OH})_{2} \mathrm{D}$ in our study, because calcium deficiency is a significant stimulator of plasma $1,25(\mathrm{OH})_{2} \mathrm{D}$, and because the rise had occurred already after 2 months and thus before the descent of 25(OH)D became obvious (Figure 3$)$. The causes of the apparent divergence of $25(\mathrm{OH}) \mathrm{D}$ and $1,25(\mathrm{OH})_{2} \mathrm{D}$ levels may be clarified in future experiments when animals on a vitamin $\mathrm{D}$ deficient and calcium deficient diet are compared with those on a vitamin $\mathrm{D}$ deficient diet on adequate supply of calcium or with those on a diet with normal vitamin $\mathrm{D}$ levels but low in calcium. This may be most interesting by enabling differentiation of $25(\mathrm{OH}) \mathrm{D}$ and $1,25(\mathrm{OH})_{2} \mathrm{D}$ effects in vivo in this minipig model which would be difficult to achieve in humans. Nevertheless, assuming one hundredth potency of $25(\mathrm{OH}) \mathrm{D}$ compared to $1,25(\mathrm{OH})_{2} \mathrm{D}$, the $\mathrm{D}_{3}$ hormonal activity of both compounds taken together still showed a decrease from about $0.69 \mathrm{nmol} / \mathrm{L}$ at baseline to $0.42 \mathrm{nmol} / \mathrm{L}$ at $t 15$. In the control group, this value increased from $0.85 \mathrm{nmol} / \mathrm{L}$ at baseline to $2.21 \mathrm{nmol} / \mathrm{L}$ at $t 15$.

Osteomalacia. In nutritional osteomalacia, defective bone mineralization leads to low BMD that might be similar to that in patients with osteoporosis $[2,8]$ and to a marked increase in nonmineralized bone matrix assessed histologically as osteoid volume or surface [21]. At the end of this experiment the minipigs on the deficient diet had developed hypovitaminosis $\mathrm{D}$ and lost bone mineral significantly according to longitudinal QCT-BMD. This loss was comparable to that in animals with GIO after 15 months on glucocorticosteroid treatment [13], although the etiologies are quite different. Their osteoid surface was significantly higher (+55\%), like in the human disease [8], indicating that mild to moderate osteomalacia had developed within 15 months. BMD of minipigs is rather high $[11,13,26]$ and in adult animals is about twice the value compared with human subjects [11]. This principal difference derogates a direct comparison of bone loss values between humans and minipigs. Minipigs are phenotypically more heterogenous than rodents and thus more animals are required to get the same statistical significance. The failure to reach significance for most crosssectional differences is owed to the small number of animals, which was yet sufficient for most parameters in longitudinal comparison when paired testing achieved higher sensitivity. This is well illustrated in case of BMD (longitudinally, change of values, significant, Figure 1; cross-sectionally, actual values, nonsignificant, Table 4). The present data, however, permit calculation of adequate sample size in future experiments.

In contrast to animals with GIO whose urinary phosphorus and BAP had decreased, 25(OH)D had increased, and $1,25(\mathrm{OH})_{2} \mathrm{D}$ was unchanged [13], these biochemical variables had increased (urinary phosphorus, $1,25(\mathrm{OH})_{2} \mathrm{D}$ ), decreased $(25(\mathrm{OH}) \mathrm{D})$, or were unchanged (BAP) in the osteomalacic animals. Based on these biochemical variables nutritional osteomalacia can be discriminated from GIO in this large animal model despite similar bone loss. 


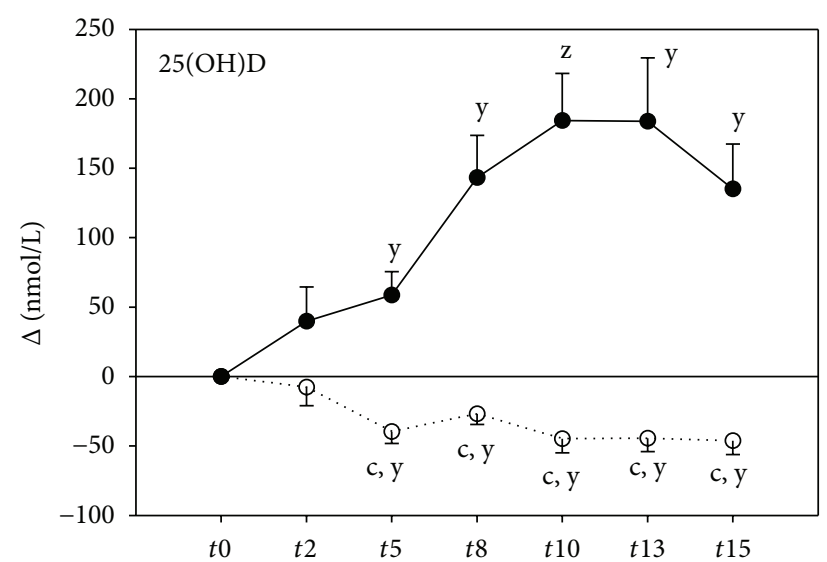

(a)

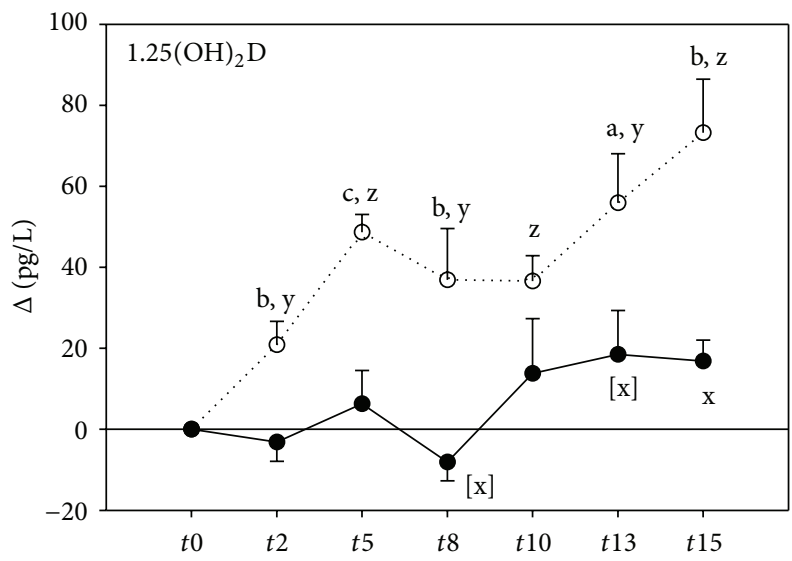

(b)

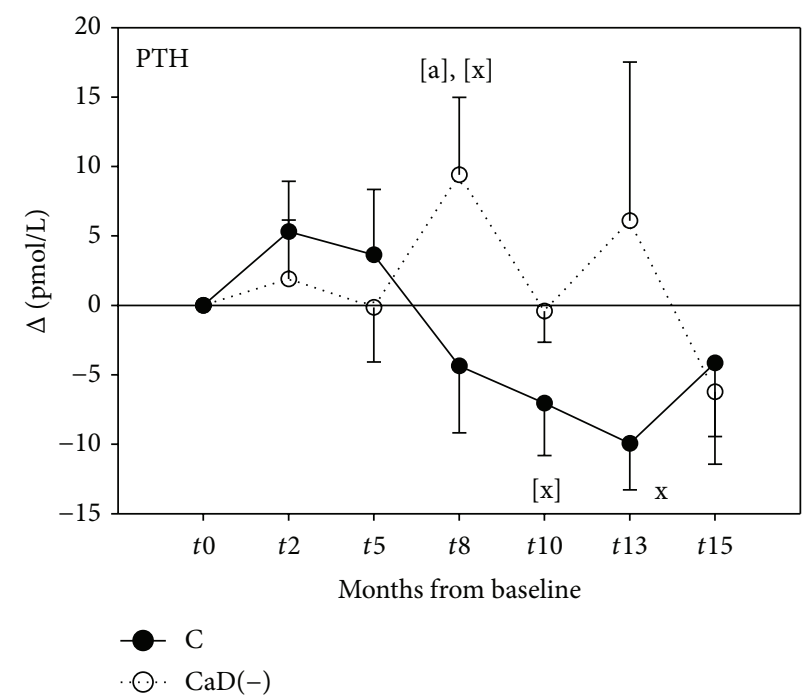

(c)

FIGURE 3: Effects of calcium and vitamin D deficiency [CaD(-); dotted line] on plasma concentrations of 25-dihydroxyvitamin $\mathrm{D}$ [25(OH)D], (a), 1,25-dihydroxyvitamin $\mathrm{D}\left[1,25(\mathrm{OH})_{2} \mathrm{D}\right]$, (b), and parathyroid hormone (PTH, (c)) compared with a control group (C; solid line). Values are changes from baseline $t 0$, with baseline values assigned to zero. Means and SEM, $n=8-10$. For baseline values see Table 1 . Significantly different from controls at a given time: ${ }^{[\mathrm{a}]} P \leq 0.1 ;{ }^{\mathrm{a}} P \leq 0.05 ;{ }^{\mathrm{b}} P \leq 0.01 ;{ }^{\mathrm{c}} P \leq 0.001$. Significantly different from baseline: ${ }^{[\mathrm{x}]} P \leq 0.1$; ${ }^{\mathrm{x}} P \leq 0.05 ;{ }^{\mathrm{y}} \mathrm{P} \leq 0.01 ;{ }^{\mathrm{z}} \mathrm{P} \leq 0.001$.

Rickets in children may result from low calcium intakes even in the face of normal vitamin D status $[1,47]$. In that situation body stores of vitamin $\mathrm{D}$ must be adequate [48] because the rise in $1,25(\mathrm{OH})_{2} \mathrm{D}$, when dietary calcium is low, aggravates an increase in $25(\mathrm{OH}) \mathrm{D}$ catabolism [49]. This in turn is the basis for the need to accessorily increase vitamin $\mathrm{D}$ intake in children with calcium deficiency rickets [50] and may be the need to accessorily increase vitamin D intake in adults on chronically low calcium intakes.

Diagnosis of osteomalacia with the help of routine serum biochemical measures as predictors is not always clear-cut [51], because abnormal values including plasma 25(OH)D may point to osteomalacia only in its severe form but miss the less severe disease [52]. Pronounced phosphaturia, typical for rickets and osteomalacia $[6,53]$, has been observed in the deficient minipigs and may have aggravated BMD loss (Figure 1). In the minipigs urinary calcium excretion, plasma PTH, and markers of bone turnover were found to have changed only slightly or nonsignificantly. This contrasts with what is typically found in patients, although with large variations $[2,21,54,55]$. The hormonal state of the estrum cycle, which we did not assess or synchronize, could have contributed to the interindividual variations of bone markers or calcium metabolism-related hormones at the certain time points. However, it could not have differently affected the cumulative and final outcomes of the two groups, like osteoid surface, bone mineral density, and vitamin D status. The study period was a long-term observation covering 15 months and thus included several of the 21-day estrogen cycles in both groups.

The rise in PTH was delayed and less distinct, perhaps because of only a modest degree of hypovitaminosis $\mathrm{D}$. 
Furthermore, the rise of $1,25(\mathrm{OH})_{2} \mathrm{D}$, as induced by the calcium insufficiency, is known to suppress PTH secretion [9]. The minipigs had a lower biological age compared with studies in the elderly or patients. Patients with a diagnosis of osteomalacia have most likely experienced nutritional or other deficiencies for many years, which may explain the more obvious clinical picture compared to the one obtained in the minipig trial.

We have to state the following limitations of the study. The assay for PTH was not specific for pigs, and thus results have to be verified in the future with porcine specific assays, even though PTH was specific enough in earlier studies to detect significantly higher values for ovariectomized pigs compared to intact controls [31]. In contrast to expectations from most observations in humans, BAP did not increase, which we cannot explain at the moment. However, BAP was specific enough to detect lower values than in control pigs after glucocorticosteroid [13] and bisphosphonate treatment [11] and to discriminate osteomalacic animals from animals with GIO [56]. Absolute values were comparable to those reported by others [57]. Therefore, comparison between and longitudinal changes within groups should be plausible in this experiment. We recognize that not all changes typically associated with osteomalacia in humans were statistically significant, because the number of animals was limited. This is valid for cross-sectional studies in particular.

In conclusion, we observed that nutritional osteomalacia and modulation of vitamin $\mathrm{D}$ metabolites and hypovitaminosis $\mathrm{D}$ can be induced and studied in minipigs when on a calcium and vitamin $\mathrm{D}$ deficient diet. The enlarged osteoid surface in combination with a significantly lower bone mineral density in the presence of hypovitaminosis $\mathrm{D}$ is characteristic of the human disease. The principal advantage of the minipig model over human studies is that the time course of the various parameters of osteomalacia and hypoor hypervitaminosis D can be evaluated over a moderately limited experimental period under controlled conditions, avoiding the problems of noncompliance beside others.

\section{Conflict of Interests}

The authors declare that they have no conflict of interests.

\section{Acknowledgments}

This work was supported by Deutsche Forschungsgemeinschaft (DFG) Project nos. DE 198/11-1, GL 289/1-1, 1-2, and Schr 430/5-1, 5-2. The authors thank Kirsten Gonda, Silvia Kaschner, Frauke Repenning, Angelika Thoss, and Anne Westphal for excellent analytical assistance and J. Kunze, H. Fischer, and D. Siewertsen for expert animal care.

\section{References}

[1] Institute of Medicine, Dietary Reference Intakes for Calcium and Vitamin D, National Academy Press, Washington, DC, USA, 2011, http://www.nap.edu/catalog/13050.html.

[2] P. Lips, "Vitamin D deficiency and secondary hyperparathyroidism in the elderly: consequences for bone loss and fractures and therapeutic implications," Endocrine Reviews, vol. 22, no. 4, pp. 477-501, 2001.

[3] Scientific Advisory Committee on Nutrition, the Stationery Office, Update on Vitamin D, London, UK, 2007, http://www .sacn.gov.uk/pdfs/sacn_position_vitamin_d_2007_05_07.pdf.

[4] J. M. Pettifor, "Nutritional rickets: deficiency of vitamin D, calcium, or both?" The American Journal of Clinical Nutrition, vol. 80, supplement 6, pp. 1725S-1729S, 2004.

[5] H. A. Bischoff-Ferrari, E. Giovannucci, W. C. Willett, T. Dietrich, and B. Dawson-Hughes, "Estimation of optimal serum concentrations of 25-hydroxyvitamin D for multiple health outcomes," American Journal of Clinical Nutrition, vol. 84, no. 1, pp. 18-28, 2006.

[6] M. F. Holick, "Resurrection of vitamin D deficiency and rickets," Journal of Clinical Investigation, vol. 116, no. 8, pp. 2062-2072, 2006.

[7] K. E. Hansen, A. N. Jones, M. J. Lindstrom, L. A. Davis, J. A. Engelke, and M. M. Shafer, "Vitamin D insufficiency: disease or no disease?" Journal of Bone and Mineral Research, vol. 23, no. 7, pp. 1052-1060, 2008.

[8] P. Lips, N. van Schoor, and N. Bravenboer, "Vitamin D-related disorders," in Primer on the Metabolic Bone Diseases and Disorders of Mineral Metabolism, C. Rosen, J. E. Compston, J. B. Lian et al., Eds., pp. 329-335, American Society of Bone and Mineral Research, Washington, DC, USA, 7th edition, 2008.

[9] C. Gennari, "Calcium and vitamin D nutrition and bone disease of the elderly," Public Health Nutrition, vol. 4, no. 2B, pp. 547$559,2001$.

[10] L. Mosekilde, "Assessing bone quality-animal models in preclinical osteoporosis research," Bone, vol. 17, supplement 4, pp. 343S-352S, 1995.

[11] C. C. Glüer, K. E. Scholz-Ahrens, A. Helfenstein et al., "Ibandronate treatment reverses glucocorticoid-induced loss of bone mineral density and strength in minipigs," Bone, vol. 40, no. 3, pp. 645-655, 2007.

[12] T. Pufe, H. Claassen, K. E. Scholz-Ahrens et al., "Influence of estradiol on vascular endothelial growth factor expression in bone: a study in Göttingen miniature pigs and human osteoblasts," Calcified Tissue International, vol. 80, no. 3, pp. 184-191, 2007.

[13] K. E. Scholz-Ahrens, G. Delling, B. Stampa et al., "Glucocorticosteroid-induced osteoporosis in adult primiparous Göttingen miniature pigs: effects on bone mineral and mineral metabolism," American Journal of Physiology, vol. 293, no. 1, pp. E385-E395, 2007.

[14] H. Hagemeister, K. E. Scholz-Ahrens, H. Schulte-Coerne, and C. A. Barth, "Plasma amino acids and cholesterol following consumption of dietary casein or soy protein in minipigs," Journal of Nutrition, vol. 120, no. 11, pp. 1305-1311, 1990.

[15] D. Zillikens, F. P. Armbruster, J. Stern, H. Schmidt-Gayk, and F. Raue, "Sensitive homologous radioimmunoassay for human parathyroid hormone to diagnose hypoparathyroid conditions," Annals of Clinical Biochemistry, vol. 24, no. 6, pp. 608-613, 1987.

[16] Y. Açil and P. K. Müller, "Rapid method for the isolation of the mature collagen crosslinks, hydroxylysylpyridinoline and lysylpyridinoline," Journal of Chromatography A, vol. 664, no. 2, pp. 183-188, 1994.

[17] C.-C. Glüer, G. Blake, Y. Lu, B. A. Blunt, M. Jergas, and H. K. Genant, "Accurate assessment of precision errors: how to measure the reproducibility of bone densitometry techniques," Osteoporosis International, vol. 5, no. 4, pp. 262-270, 1995. 
[18] F. Linde, I. Hvid, and F. Madsen, "The effect of specimen geometry on the mechanical behaviour of trabecular bone specimens," Journal of Biomechanics, vol. 25, no. 4, pp. 359-368, 1992.

[19] J. Schormüller, Handbuch der Lebensmittelchemie IV, Springer, Berlin, Germany, 1969.

[20] M. Hahn, M. Vogel, and G. Delling, "Undecalcified preparation of bone tissue: report of technical experience and development of new methods," Virchows Archiv A, vol. 418, no. 1, pp. 1-7, 1991.

[21] A. J. Reginato and J. A. Coquia, "Musculoskeletal manifestations of osteomalacia and rickets," Best Practice and Research: Clinical Rheumatology, vol. 17, no. 6, pp. 1063-1080, 2003.

[22] DGE, ÖGE, SGE, and SVE, Eds., Referenzwerte für die Nährstoffzufuhr, 1. Auflage, 4. Korrigierter Nachdruck, Neuer Umschau Buchverlag Neustadt a. W., 2012.

[23] "Nutrition and bone health: with particular reference to calcium and vitamin D. Report of the Subgroup on Bone Health, Working Group on the Nutritional Status of the Population of the Committee on Medical Aspects of the Food Nutrition Policy," Reports on Health and Social Subjects, vol. 49, pp. 1-24, 1998.

[24] M. F. Holick and T. C. Chen, "Vitamin D deficiency: a worldwide problem with health consequences," American Journal of Clinical Nutrition, vol. 87, supplement 4, pp. 1080S-1086S, 2008.

[25] E. R. Miller and D. E. Ullrey, "The pig as a model for human nutrition," Annual Review of Nutrition, vol. 7, pp. 361-382, 1987.

[26] K. E. Scholz-Ahrens and J. Schrezenmeir, "Effects of bioactive substances in milk on mineral and trace element metabolism with special reference to casein phosphopeptides," British Journal of Nutrition, vol. 84, no. 1, pp. S147-S153, 2000.

[27] M. E. Tumbleson and L. B. Schook, Eds., Advances in Swine in Biomedical Research, vol. 1-2, Plenum Press, New York, NY, USA, 1996.

[28] R. L. Horst, J. L. Napoli, and E. T. Littledike, "Discrimination in the metabolism of orally dosed ergocalciferol and cholecalciferol by the pig, the rat and chick," Biochemical Journal, vol. 204, no. 1, pp. 185-189, 1982.

[29] H. Claassen, C. Cellarius, K. E. Scholz-Ahrens et al., "Extracellular matrix changes in knee joint cartilage following bone-active drug treatment," Cell and Tissue Research, vol. 324, no. 2, pp. 279-289, 2006

[30] T. Pufe, K. E. Scholz-Ahrens, A. T. M. Franke et al., “The role of vascular endothelial growth factor in glucocorticoid-induced bone loss: evaluation in a minipig model," Bone, vol. 33 , no. 6 , pp. 869-876, 2003.

[31] K. E. Scholz-Ahrens, G. Delling, P. W. Jungblut, E. Kallweit, and C. A. Barth, "Effect of ovariectomy on bone histology and plasma parameters of bone metabolism in nulliparous and multiparous sows," Zeitschrift für Ernährungswissenschaft, vol. 35, no. 1, pp. 13-21, 1996.

[32] EFSA, "Scientific opinion on safety and efficacy of 25hydroxycholecalciferol as a feed additive for poultry and pigs," The EFSA Journal, vol. 969, pp. 1-32, 2009.

[33] R. Vieth, "Vitamin D toxicity, policy, and science," Journal of Bone and Mineral Research, vol. 22, no. 2, pp. V64-V68, 2007.

[34] K. D. Cashman, J. M. W. Wallace, G. Horigan et al., "Estimation of the dietary requirement for vitamin $\mathrm{D}$ in free-living adults $\geq 64$ y of age," American Journal of Clinical Nutrition, vol. 89, no. 5, pp. 1366-1374, 2009.

[35] V. Chel, H. A. H. Wijnhoven, J. H. Smit, M. Ooms, and P. Lips, "Efficacy of different doses and time intervals of oral vitamin D supplementation with or without calcium in elderly nursing home residents," Osteoporosis International, vol. 19, no. 5, pp. 663-671, 2008.

[36] V. Mocanu, P. A. Stitt, A. R. Costan et al., "Long-term effects of giving nursing home residents bread fortified with $125 \mu \mathrm{g}(5000$ $\mathrm{IU})$ vitamin $\mathrm{D}_{3}$ per daily serving," American Journal of Clinical Nutrition, vol. 89, no. 4, pp. 1132-1137, 2009.

[37] S. O’Donnell, A. Cranney, T. Horsley et al., "Efficacy of food fortification on serum 25-hydroxyvitamin D concentrations: systematic review," American Journal of Clinical Nutrition, vol. 88, no. 6, pp. 1528-1534, 2008.

[38] R. Vieth, "Experimentally observed vitamin D requirements are higher than extrapolated ones," American Journal of Clinical Nutrition, vol. 90, no. 4, pp. 1114-1115, 2009.

[39] S. M. Smith, K. K. Gardner, J. Locke, and S. R. Zwart, "Vitamin D supplementation during Antarctic winter," American Journal of Clinical Nutrition, vol. 89, no. 4, pp. 1092-1098, 2009.

[40] M. Janet Barger-Lux and R. P. Heaney, "Effects of above average summer sun exposure on serum 25-hydroxyvitamin D and calcium absorption," The Journal of Clinical Endocrinology and Metabolism, vol. 87, no. 11, pp. 4952-4956, 2002.

[41] C. F. Garland, C. B. French, L. L. Baggerly, and R. P. Heaney, "Vitamin D supplement doses and serum 25-hydroxyvitamin $\mathrm{D}$ in the range associated with cancer prevention," Anticancer Research, vol. 31, no. 2, pp. 607-612, 2011.

[42] J. N. Hathcock, A. Shao, R. Vieth, and R. Heaney, "Risk assessment for vitamin D," American Journal of Clinical Nutrition, vol. 85, no. 1, pp. 6-18, 2007.

[43] R. P. Heaney, "Vitamin D: criteria for safety and efficacy," Nutrition Reviews, vol. 66, no. 2, pp. S178-S181, 2008.

[44] P. Lips, R. Bouillon, N. M. Van Schoor et al., "Reducing fracture risk with calcium and vitamin D," Clinical Endocrinology, vol. 73, no. 3, pp. 277-285, 2010.

[45] J. B. Eastwood, H. E. De Wardener, R. W. Gray, and J. L. Lemann Jr., "Normal plasma-1,25-(OH)2-vitamin-D concentrations in nutritional osteomalacia," The Lancet, vol. 1, no. 8131, pp. 13771378, 1979.

[46] A. G. Need and B. E. C. Nordin, "Misconceptions-vitamin D insufficiency causes malabsorption of calcium," Bone, vol. 42, no. 6, pp. 1021-1024, 2008.

[47] F. Okonofua, D. S. Gill, Z. O. Alabi, M. Thomas, J. L. Bell, and P. Dandona, "Rickets in Nigerian children: a consequence of calcium malnutrition," Metabolism, vol. 40, no. 2, pp. 209-213, 1991.

[48] F. Bronner, "Recent developments in intestinal calcium absorption," Nutrition Reviews, vol. 67, no. 2, pp. 109-113, 2009.

[49] M. Davies, S. E. Heys, P. L. Selby, J. L. Berry, and E. B. Mawer, "Increased catabolism of 25-hydroxyvitamin D in patients with partial gastrectomy and elevated 1,25-dihydroxyvitamin D levels. Implications for metabolic bone disease," The Journal of Clinical Endocrinology and Metabolism, vol. 82, no. 1, pp. 209212, 1997.

[50] T. D. Thacher, P. R. Fischer, M. O. Obadofin, M. A. Levine, R. J. Singh, and J. M. Pettifor, "Comparison of metabolism of vitamins $\mathrm{D}_{2}$ and $\mathrm{D}_{3}$ in children with nutritional rickets," Journal of Bone and Mineral Research, vol. 25, no. 9, pp. 1988-1995, 2010.

[51] H. Peach, J. E. Compston, S. Vedi, and L. W. L. Horton, "Value of plasma calcium, phosphate, and alkaline phosphatase measurements in the diagnosis of histological osteomalacia," Journal of Clinical Pathology, vol. 35, no. 6, pp. 625-630, 1982.

[52] C. Meier, M. J. Seibel, and M. E. Kraenzlin, "Use of bone turnover markers in the real world: are we there yet?" Journal of Bone and Mineral Research, vol. 24, no. 3, pp. 386-388, 2009. 
[53] M. J. Pitt, "Rickets and osteomalacia are still around," Radiologic Clinics of North America, vol. 29, no. 1, pp. 97-118, 1991.

[54] S. R. Peacey, "Routine biochemistry in suspected vitamin D deficiency," Journal of the Royal Society of Medicine, vol. 97, no. 7, pp. 322-325, 2004.

[55] M. P. Björkman, A. J. Sorva, J. Risteli, and R. S. Tilvis, "Low parathyroid hormone levels in bedridden geriatric patients with vitamin D deficiency," Journal of the American Geriatrics Society, vol. 57, no. 6, pp. 1045-1050, 2009.

[56] K. E. Scholz-Ahrens, C. C. Glüer, W. Timm, Y. Açil, W. YanClassen, and J. Schrezenmeir, "Goettingen minipigs-a model for $\mathrm{Ca} / \mathrm{Vit} \mathrm{D}$-deficiency osteomalacia and steroid-induced osteoporosis," Journal of Bone and Mineral Research, vol. 23, p. S217, 2008, abstract 445.

[57] H. Tsutsumi, K. Katagiri, M. Morimoto, T. Nasu, M. Tanigawa, and K. Mamba, "Diurnal variation and age-related changes of bone turnover markers in female Göttingen minipigs," Laboratory Animals, vol. 38, no. 4, pp. 439-446, 2004. 


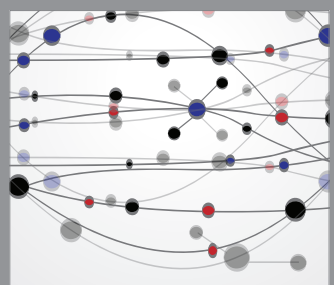

The Scientific World Journal
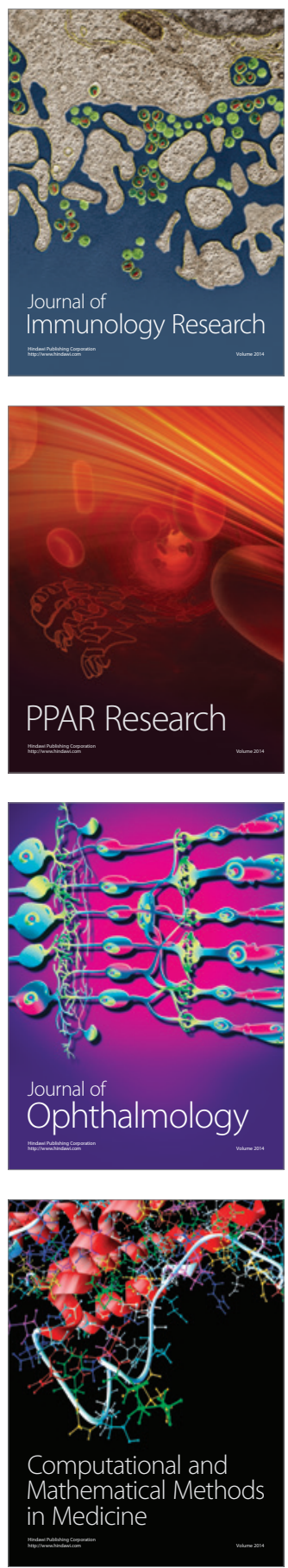

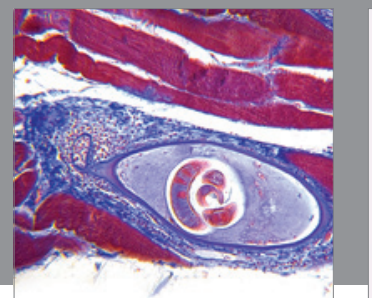

Gastroenterology

Research and Practice
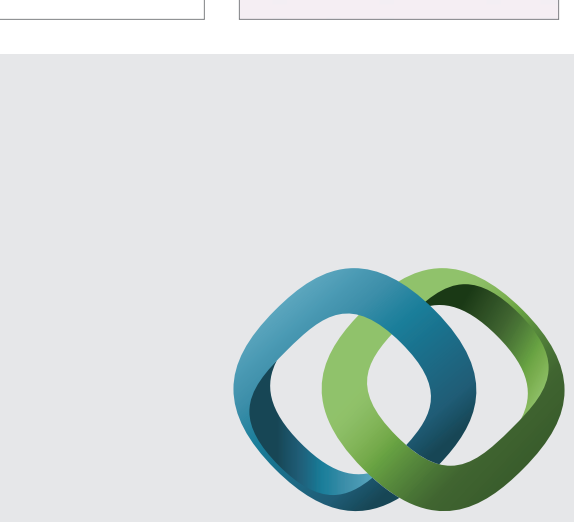

\section{Hindawi}

Submit your manuscripts at

http://www.hindawi.com
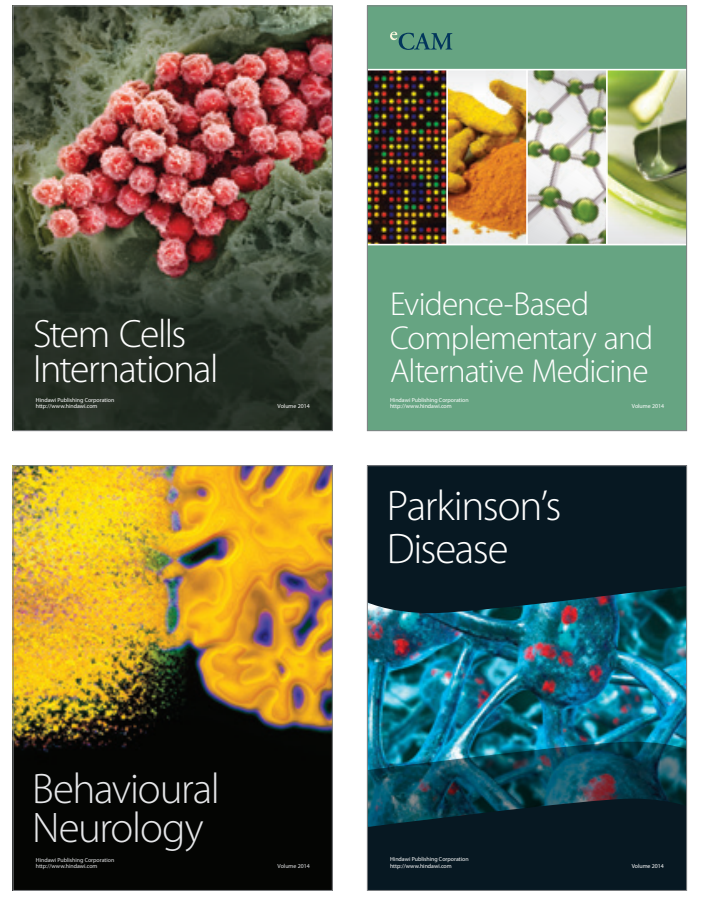
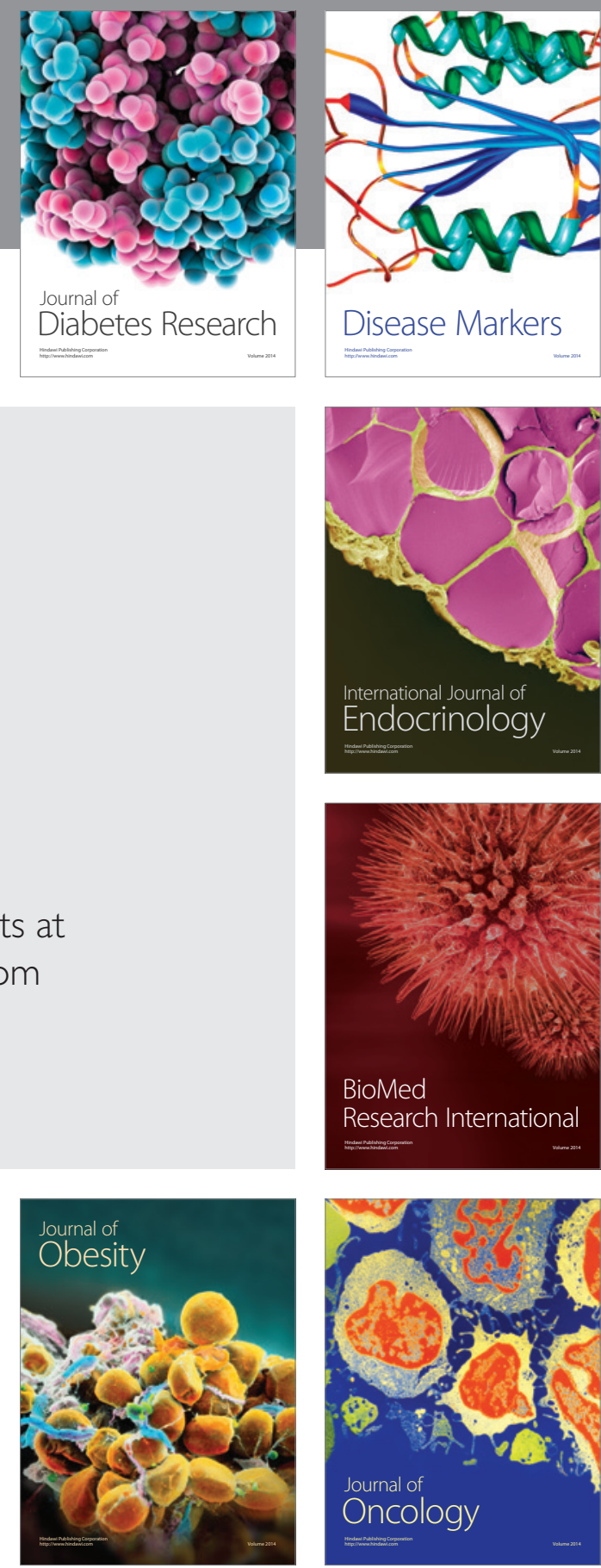

Disease Markers
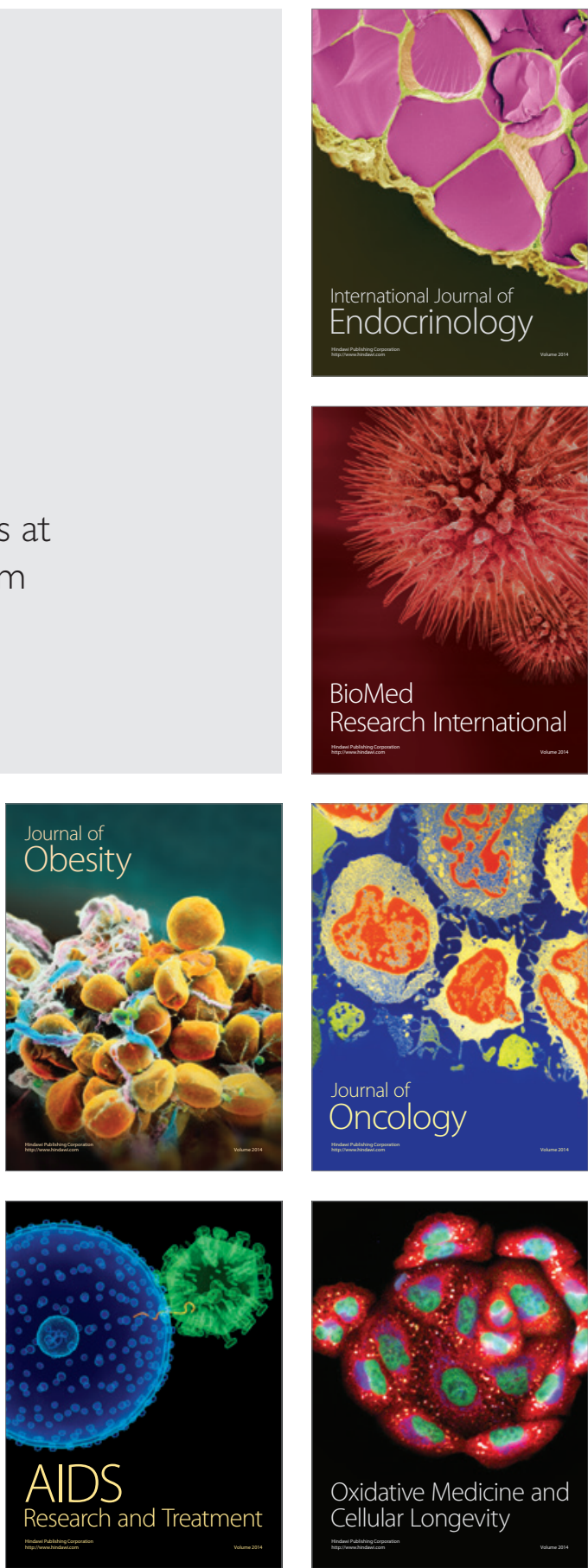